\title{
Meningkatkan Kemampuan Siswa SDIT Miftahul Ulum Pada Operasi Bilangan Bulat Melalui CAI-Contextual
}

\author{
Nanang ${ }^{*}$, Awan Sukandar ${ }^{2}$ \\ Program Studi Pendidikan Matematika, IPI Garut \\ Jalan Pahlawan Nomor 32, Garut, Jawa Barat, Indonesia \\ 1*na2ngdr.64@gmail.com
}

Pendidikan Matematika, SDIT Miftahul Ulum

Kp. Naringgul, Sirnajaya, Cisurupan, Kabupaten Garut, Jawa Barat, Indonesia

${ }^{2}$ awansukandar@gmail.com

Artikel diterima: 22-11-2019, direvisi: 29-01-2020, diterbitkan: 31-01-2020

\begin{abstract}
Abstrak
Latar belakang penelitian ini yaitu pembelajaran guru-guru SD di Cisurupan Garut yang pada umumnya lepas dengan masalah kehidupan sehari-hari dan tidak menggunakan komputer sebagai media pembelajaran. Dikhawatirkan pembelajaran menjadi kurang bermakna. Solusinya, dilakukan penerapan hasil pelatihan berupa perangkat CAI-Contextual yang merupakan wujud dari pengabdian masyarakat pada guru-guru anggota PGRI Cabang Cisurupan Garut yang didanai oleh DRPM Dirjend Ristek Dikti. Penelitian bertujuan mengetahui peningkatan kemampuan operasi bilangan bulat siswa antara sebelum dengan sesudah penerapan CAI-Contextual. Penelitian merupakan penelitian tindakan kelas (PTK), terdiri dari tiga siklus. Subjek penelitiannya adalah 34 siswa Kelas V SDIT Miftahul Ulum Cisurupan Kabupaten Garut Tahun Pelajaran 2019/2020. Dari hasil pengujian gain ternormalisasi, diketahui bahwa kualitas peningkatan kemampuan Operasi Bilangan Bulat siswa dari sebelum dengan setelah memperoleh CAI-Contextual dari Siklus I ke Siklus II tergolong sedang dan dari Siklus I ke Siklus III tergolong tinggi, sedangkan dari Siklus II ke Siklus III tergolong rendah.

Kata Kunci: CAl-Contextual, meningkatkan, kemampuan, operasi, bilangan bulat .

\section{Improving Students' Capability In Miftahul Ulum SDIT On Round Number Operations Through CAl-Contextual}

Abstract

The background of this research is the learning of elementary school teachers in Cisurupan Garut who are generally free from problems of daily life and do not use computers as learning media. It is feared learning will become less meaningful. The solution is to implement the results of the training in the form of a CAI-Contextual tool which is a form of community service to the teachers of the PGRI Cisurupan Branch in Garut, which is funded by the Directorate General of Research and Technology DRPM. The study aims to determine the increase in students' integer operating skills between before and after the application of CAIContextual. The study is a classroom action research (CAR), consisting of three cycles. The research subjects were 34 students of Class V SDIT Miftahul Ulum Cisurupan, Garut Regency in the Academic Year 2019/2020. From the normalized gain test results, it is known that the quality of the improvement of students' Round Number Operations ability from before to after obtaining CAI-Contextual from Cycle I to Cycle II is classified as moderate and from Cycle I to Cycle III is high, while from Cycle II to Cycle III is low.

Keywords: CAl-Contextual, improve, ability, operation, integer.
\end{abstract}




\section{Pendahuluan}

Matematika sebagai ilmu universal yang mendasari perkembangan teknologi modern (Afriansyah, dkk., 2019), mempunyai peran penting dalam berbagai disiplin dan memajukan daya pikir manusia. Menurut Deni (2018), untuk menguasai dan menciptakan teknologi di masa depan diperlukan penguasaan matematika yang kuat sejak dini. Hal ini tersirat pada Lampiran Peraturan Menteri Pendidikan Nasional Nomor 22 Tahun 2006 tentang Standar Isi dijelaskan bahwa mata pelajaran Matematika perlu diberikan kepada semua peserta didik mulai dari sekolah dasar. Hal ini dimaksudkan untuk membekali peserta didik dengan kemampuan berpikir logis, analitis, sistematis, kritis, dan kreatif (Tarlina \& Afriansyah, 2016), serta kemampuan bekerjasama. Kompetensi tersebut diperlukan agar peserta didik dapat memiliki kemampuan memperoleh, mengelola, dan memanfaatkan informasi untuk bertahan hidup pada keadaan yang selalu berubah, tidak pasti, dan kompetitif.

Akan tetapi, dalam ulasan Tentorku (2015) matematika adalah salah satu mata pelajaran yang banyak ditakuti oleh peserta didik. Banyak faktor yang menjadi penyebab kegagalan peserta didik dalam belajar matematika (Afriansyah, 2016), antara lain strategi, pendekatan, atau metode pembelajaran yang diterapkan oleh guru kurang tepat. Pendekatan pengajaran matematika di Indonesia, pada umumnya menurut Sutrisno (2013), masih menggunakan pendekatan tradisional atau mekanistik yang menekankan 'drill and practice', procedural serta menggunakan rumus dan algoritma sehingga siswa dilatih mengerjakan soal seperti mekanik atau mesin. Hal ini berakibat bila siswa diberikan soal yang berbeda dengan soal latihan, mereka akan membuat kesalahan atau 'error' seperti komputer. Mereka tidak terbiasa memecahkan masalah (Sopian \& Afriansyah, 2017) yang banyak di operasi penjumlahan dan pengurangan.

Kurang optimalnya dalam mengembangkan strategi pembelajaran yang dilaksanakan di kelas, sangat berpengaruh terhadap pencapaian hasil belajar siswa. Menurut Setyaningsih, Aryanto, \& Rita (2006) bahwa dalam pembelajaran matematika yang banyak menekankan pada ketuntasan penyelesaian materi pelajaran daripada meningkatkan kualitas, dengan kata lain lebih banyak menekankan pada produk daripada proses pembelajaran, sehingga pembelajaran matematika berorientasi pada psikologi perilaku dan strukturalis, yang lebih menekankan drill. Hal ini merupakan penyiapan yang kurang baik untuk meningkatkan kemampuan siswa dalam Operasi Bilangan Bulat.

Afriansyah (2014) memaparkan suatu aktivitas kegiatan belajar bilangan bulat dalam operasi penjumlahan dan pengurangan pada level SD. Fuadiah (2017) mengemukakan suatu rangkaian pembelajaran bilangan bulat negative berdasarkan teori situasi didaktis di sekolah. Suwarto (2018) memaparkan konsep bilangan pecahan melalui garis bilangan.

Dalam proses belajar mengajar untuk meningkatkan kemampuan Operasi Bilangan Bulat dan menghilangkan image negative terhadap pelajaran matematika yang sulit (Siregar, 2016), seorang guru tidak hanya memiliki kemampuan mengembangkan ilmu pengetahuan saja, tetapi lebih pada memiliki kemampuan melaksanakan pembelajaran yang menarik dan bermakna bagi siswa (Afriansyah, 2016). Agar pembelajaran menarik dan bermakna, menurut Nanang 
(2018) sebaiknya pembelajaran matematika harus terkait dengan konteks lingkungan. Pembelajaran tersebut dikenal dengan istilah contextual teaching and learning (CTL). Menurut Sanjaya (2016; Sipayung, 2018; Damayanti \& Afriansyah, 2018), CTL adalah suatu strategi pembelajaran yang menekankan kepada proses keterlibatan siswa secara penuh untuk dapat menemukan materi yang dipelajari dan menghubungkannya dengan situasi kehidupan nyata sehingga mendorong siswa untuk dapat menerapkannya dalam kehidupan mereka.

Dalam pembelajaran matematika, salah satu cara dan pendekatan untuk meciptakan pembelajaran yang menarik dan menyenangkan serta dapat mendorong siswa bersikap aktif, kreatif dan, inovatif adalah dengan pendekatan pembelajaran Contextual (Latipah \& Afriansyah, 2018) yang memanfaatkan komputer. Pemanfaatan komputer dalam teknologi informasi (TI) Menurut Yaniawati (Nanang, 2016), selain sebagai upaya mengatasi permasalahan teknis pembelajaran, juga sebagai media pembelajaran dan sumber ajar. Menurut Nanang (2019) dalam mengembangkan bahan ajar interaktif yang sering dikenal dengan pembelajaran berbasis computer salah satunya adalah Computer Assistance Instruction (CAl) yang tiada lain merupakan hasil inovasi. Artinya para guru harus sadar bahwa inovasi dan adopsi terhadap perkembangan keilmuan dibidang pendidikan dan pembelajaran ini sangat penting.

Hal ini menarik untuk dikaji melalui penelitian di SDIT Miftahul Ulum Cisurupan Kabupaten Garut, mengingat Anak-anak Sekolah Dasar (SD) yang berumur antara tujuh sampai dengan 12 tahun pada dasarnya perkembangan intelektualnya termasuk dalam tahap operasional kongkret, sebab berfikir logiknya didasarkan atas manipulasi fisik dari obyek-obyek. Dengan kata lain penggunaan CAI dalam pembelajaran matematika di SD memang diperlukan, karena dapat membantu mengkonkritkan objek-objek yang sedang dipelajari sesuai dengan tahap berpikir anak. Pendekatan pembelajaran Contextual dengan pemamfaatan CAI diharapkan dapat meningkatkan kemampuan Operasi Bilangan Bulat yang selama ini dirasakan sangat jauh dari harapan. Hal ini diperoleh dari hasil ulangan harian pada pokok bahasan bilangan bulat matematika Kelas $\vee$ tahun sebelumnya, siswa yang mendapat nilai di atas 50 sebanyak 18 siswa dari 34 siswa, ini membuktikan bahwa lebih kurang hanya 53\% siswa yang bisa memahami operasi hitung bilangan bulat.

Berdasarkan latar belakang di atas, maka rumusan permasalahan penelitian ini adalah bagaimanakah kualitas peningkatan kemampuan Operasi Bilangan Bulat (KOBB) siswa Kelas V SDIT Miftahul Ulum Cisurupan dari sebelum dengan sesudah CAl-Contextual? Tujuannya yaitu untuk mengetahui peningkatan KOBB siswa antara sebelum dengan sesudah penerapan CAI-Contextual

\section{Metode}

Penelitian ini merupakan penelitian tindakan kelas (PTK) yang merupakan suatu pencermatan terhadap kegiatan belajar melalui tindakan yang sengaja dimunculkan dan terjadi dalam sebuah kelas secara bersama. Penelitian tindakan yang ideal menurut Arikunto (2008) dilakukan secara berpasangan antara pihak yang melakukan tindakan dan pihak yang mengamati proses jalannya tindakan. Istiah untuk cara ini adalah penelitian kolaborasi. PTK 
dalam penelitian ini secara garis besar terdiri dari empat tahap, yaitu:

1. Perencanaan. Peneliti dengan guru mitra merencanakan tindakan yang akan dilakukan. Peneliti bersama guru mitra ditiap siklus menyusun perangkat pembelajaran dan instrumen penelitian.

2. Tindakan. Tindakan merupakan tahap pelaksanaan dari perencanaan. Dan merupakan implementasi atau penerapan isi rancangan yaitu mengenakan tindakan kelas. Pada tahap ini peneliti melaksanakan tindakan yang telah disepakati bersama dengan guru mitra pada tahap perencanaan. Pada siklus I, guru melaksanakan pembelajaran konvensional (tanpa CAI-Contextual). Pada siklus II, guru melaksanakan pembelajaran Contextual (tanpa CAI). Sedangkan pada pada siklus III, guru melaksanakan CAI-Contextual.

3. Pengamatan. Pada tahap ini guru lain yang bertindak sebagai observer mengobservasi tindakan yang sedang dilakukan oleh peneliti dan guru mitra dengan teknik observasi catatan. Pada tiap siklus, peneliti dan guru mitra dibantu guru lain melakukan: Observasi Kegiatan Pembelajaran, Pemberian Latihan, Tes KOBB, dan penskoran serta penilaian tes KOBB.

4. Refleksi. Guru mitra dan peneliti mendiskusikan hasil tindakan yang terjadi di kelas penelitian. Dengan demikian refleksi dapat ditentukan setelah adanya implementasi tindakan dan hasil observasi. Refleksi yang dilakukan tiap siklus berupa: Analisis tes, Interpretasi tes, dan eksplanasi kekurangan dan kelebihan Tindakan. Setelah melakukan refleksi biasanya muncul permasalahan atau pemikiran baru, sehingga merasa perlu untuk melakukan perencanaan ulang, pengamatan ulang dan refleksi ulang.

Subjek dari penelitian ini adalah siswa Kelas V Sekolah Dasar Islam Terpadu (SDIT) Miftahul Ulum. Seluruh siswa akan dikenai tindakan, hal ini karena penelitian tindakan kelas adalah penelitian yang mengikuti alur pembelajaran sebenarnya. Pertimbangan pemilihan Kelas $\mathrm{V}$ sebagai subjek penelitian, karena Kelas $V$ merupakan salah satu kelas yang diajar matematika oleh peneliti. Alasan lain siswa Kelas V SDIT Miftahul Ulum dijadikan subjek penelitian, selain dikarenakan guru mitra sebagai guru matematikanya, juga dikarenakan siswa-siswa Kelas V SDIT Miftahul Ulum banyak yang lemah dalam memahami konsep matematik.

SDIT Miftahul Ulum beralamat di Kp. Naringgul RT 4 RW 3 Desa Sirnajaya Kecamatan Cisurupan Kab. Garut. Letaknya di pegunungan dan lokasinya sangat jauh dari kota Garut. Waktu pelaksanaan penelitian di lapangan pada bulan September 2019 di Kelas V SDIT Miftahul Ulum yang terdiri dari 34 siswa. Guru mitra yang berkolaborasi dengan Penulis sendiri merupakan guru dan Kepala SDIT Miftahul Ulum.

Untuk memperoleh data yang diperlukan, dalam penelitian ini digunakan instrumen tes KOBB. Pemilihan soal berdasarkan materi yang telah dipelajari siswa. Soal-soal yang terpilih dimodifikasi hanya terbatas pada redaksi dan istilah yang disesuaikan dengan keadaan siswa berada, sedangkan yang lainnya sesuai dengan aslinya. Beberapa pertimbangan mengadopsi soal-soal dari buku pelajaran, diantaranya: 1) soal-soalnya disusun oleh pakar penulis buku pelajaran matematika yang didampingi oleh editor buku pelajaran matematika dan telah memperoleh ISBN, sehingga tidak terlalu diragukan mengenai validitasnya, 2) ruang 
lingkup materi bahan tes sudah diterima siswa saat Kelas $\vee$ Semester 1, 3) tingkat kesukarannya bervariasi, dan kemampuan yang terkait sesuai dengan harapan Kurikulum 2013. Materi yang diteskan meliputi operasi penjumlahan dan pengurangan bilangan bulat (Siklus I), operasi perkalian bilangan bulat (Siklus II), operasi pembagian (Siklus III). Soal untuk tes kemampuan pemecahan masalah ini semuanya berbentuk uraian.

Sebelum digunakan, soal tes kemampuan operasi bilangan bulat (KOBB) untuk ketiga siklus tersebut divalidasi untuk melihat validitas isi dan validitas muka. Uji validitas muka dan isi dilakukan oleh lima orang penimbang yang berlatar belakang guru matematika yang dianggap ahli. Penimbang diminta untuk memberikan pertimbangannya terhadap soal tes kemampuan Operasi Bilangan Bulat. Menurut Nanang (2018), untuk mengukur validasi muka, pertimbangan didasarkan pada: kejelasan bahasa/redaksional, kejelasan gambar/ representasi. Sedangkan untuk mengukur validasi isi, pertimbangan didasarkan pada: materi pokok yang diberikan, tujuan yang ingin dicapai, aspek kemampuan yang diukur, tingkat kesukaran untuk siswa Kelas V. Hasil pertimbangan mengenai validitas muka dan validitas isi dari kelima orang ahli terhadap soal tes KOBB untuk siklus I, II, dan III adalah tidak terdapat perbedaan hasil pertimbangan validator terhadap tes kemamuan Operasi Bilangan Bulat pada aspek validitas muka dan isi, dan pada umumnya menyatakan valid.

Untuk memperoleh data kemampuan Operasi Bilangan Bulat, dilakukan penskoran terhadap jawaban siswa untuk setiap butir soal. Data yang diperoleh dari hasil penelitian dengan menggunakan semua instrumen penelitian, selanjut-nya dianalisis menggunakan prinsip-prinsip yang meliputi data penelitian berasal dari sumber, kemudian dilakukan analisis dari data berdasar-kan masing-masing sumber data, dan diakhiri dengan melihat hubungan dari fakta yang satu dengan fakta yang lainnnya. Selanjutnya penulis berusaha untuk membuat kesimpulan tentang KOBB siswa dalam pembelajaran matematika akibat CAl-Contextual.

Proses pengolahan dan analisis data untuk mengetahui sejauh mana peningkatan Operasi Bilangan Bulat siswa, digunakan tes KOBB Siklus I, II, dan III (masing-masing berupa tes uraian yang terdiri dari 3 soal). Dari hasil tes KOBB Siklus I, II, dan III, dilihat peningkatannya dengan menggunakan gain ternormalisasi dengan rumus:

Gain Ternormalisasi $(g)=\frac{S_{k o r_{2}}-S_{k o r_{1}}}{\text { Skor }_{\text {Ideal }}-S k o r_{1}}$

Kategori gain ternormalisasi (g) menurut Meltzer (2002):

$$
\begin{aligned}
\quad \mathrm{g}<0,3 & \text { : rendah; } \\
0,3 \leq \mathrm{g}<0,7 & \text { : sedang; } \\
0,7 \leq \mathrm{g} & \text { : tinggi }
\end{aligned}
$$

Tahapan alur kerja PTK ini didasarkan pada pendapat Arikunto (2008), yaitu diawali dengan studi pendahuluan untuk merumuskan identifikasi masalah, rumusan masalah, tindakan yang akan digunakan, dan studi literatur yang pada akhirnya diperoleh perangkat penelitian berupa bahan ajar, pendekatan pembelajaran, instrumen penelitian.

\section{Hasil dan Pembahasan}

\section{A. Hasil Penelitian}

\section{KOBB Siswa pada Siklus I}

Data penelitian yang berkenaan dengan kemampuan Operasi Bilangan Bulat (KOBB) 
pada siklus I diperoleh melalui tes KOBB pada topik Operasi penjumlahan dan pengurangan Bilangan bulat. Rerata gain yang merupakan gambaran penilaian hasil KOBB pada siklus I disajikan pada Tabel 1.

Tabel 1 memberikan gambaran bahwa rata-rata nilai KOBB siswa pada siklus I bahwa banyaknya siswa yang tuntas hanya 13 siswa dari 34 siswa yang ada (38,24\%). Dengan kata lain, pada Siklus I KOBB siswa pada topik Operasi penjumlahan dan pengurangan Bilangan bulat masih rendah.

\section{KOBB Siswa pada Siklus II}

Data penelitian yang berkenaan dengan KOBB pada siklus II diperoleh melalui tes KOBB siklus II pada topik Operasi perkalian Bilangan bulat. Rata-rata gain yang merupakan gambaran peningkatan KOBB siklus II berdasarkan Siklus I selengkapnya dapat dilihat pada Tabel 2.

$$
\begin{aligned}
& \text { Peningkatan: } \\
& \begin{aligned}
g & =\frac{\text { Nilai Siklus II }- \text { Nilai Siklus I }}{\text { Nilai Ideal }- \text { Nilai Siklus I }} \\
& =\frac{68,82-17,38}{100-17,38}=\frac{51,44}{82,62}=0,62
\end{aligned}
\end{aligned}
$$

Kategori gain ternormalisasi: $0,3 \leq \mathrm{g}=0,62<$ 0,7: sedang

Tabel 2 memberikan gambaran bahwa rata-rata nilai KOBB siswa pada siklus II lebih tinggi dibandingkan dengan rata-rata nilai siklus I. Demikian juga banyaknya siswa yang tuntas pada siklus II lebih banyak dibandingkan dengan siklus I. Banyak siswa yang tuntas pada Siklus II sebanyak 23 siswa dari 34 siswa (67,65\%). Hal ini menujukkan terjadinya peningkatan banyaknya siswa yang tuntas dari hasil tes KOBB pada siklus II. Kriteria peningkatan berdasarkan gain ternormalisasi dari KOBB siklus I ke KOBB siklus II termasuk sedang.

\section{KOBB Siswa pada Siklus III}

Data penelitian yang berkenaan dengan kemampuan Operasi Bilangan Bulat (KOBB) pada siklus III diperoleh melalui tes KOBB pada topik Pembagian Bilangan Bulat. Rerata gain yang merupakan gambaran peningkatan KOBB berdasarkan Siklus I selengkapnya dapat dilihat pada Tabel 3.

\begin{tabular}{|c|c|c|}
\hline & Nilai Siklus I & $\%$ \\
\hline Rata-rata & 17,38 & \\
\hline Subjek yang Tuntas & $\begin{array}{r}13 \\
38,24 \\
\end{array}$ & \\
\hline $\begin{array}{c}\text { Subjek yang Tidak } \\
\text { Tuntas }\end{array}$ & $\begin{array}{r}21 \\
61,76\end{array}$ & \\
\hline
\end{tabular}

Tabel 1.

Ketuntasan pada Siklus I

Catatan: Nilai ideal KOBB 100 dan KKM 65

Tabel 2.

Ketuntasan dan Peningkatan Siklus II dari Silus I Siklus II Siklus I g Kriteria

\begin{tabular}{lcccc|}
\hline Rata-rata & 68.82 & 17,38 & 0,62 & Sedang \\
\hline $\begin{array}{l}\text { Subjek } \\
\text { yang }\end{array}$ & 23 & 13 & & \\
Tuntas & & & \\
\hline $\begin{array}{l}\text { Subjek } \\
\text { yang }\end{array}$ & 11 & 21 & \\
Tidak & & & \\
Tuntas & & & \\
Catatan: Nilai ideal KOBB 100 dan KKM 65
\end{tabular}

Tabel 3.

Ketuntasan dan Peningkatan Siklus III dari Siklus I

\begin{tabular}{lcccc}
\hline & Siklus III & Siklus I & g & Kriteria \\
\hline $\begin{array}{l}\text { Rata- } \\
\text { rata }\end{array}$ & 76,57 & 17,38 & 0,72 & Tinggi \\
\hline $\begin{array}{l}\text { Subjek } \\
\text { yang } \\
\text { Tuntas }\end{array}$ & 28 & 13 & & \\
$\begin{array}{l}\text { Subjek } \\
\text { yang } \\
\text { Tidak } \\
\text { Tuntas }\end{array}$ & 6 & 21 & \\
Catatan: Nilai ideal KOBB 100 dan KKM 65 & \\
\hline
\end{tabular}


Peningkatan :

$$
\begin{aligned}
& g=\frac{\text { Nilai Siklus III }- \text { Nilai Siklus I }}{\text { Nilai Ideal-Nilai Siklus I }} \\
& =\frac{76,57-17,38}{100-17,38}=\frac{59,19}{82,62}=0,72
\end{aligned}
$$

Kategori gain ternormalisasi: $0,7 \leq \mathrm{g}=0,72$ : tinggi.

Tabel 3 memberikan gambaran bahwa rata-rata nilai KOBB siswa pada siklus III lebih tinggi dibandingkan dengan rata-rata nilai siklus I. Demikian juga banyaknya siswa yang tuntas pada siklus III lebih banyak dibandingkan dengan siklus I. Banyak siswa yang tuntas pada Siklus III sebanyak 28 siswa dari 34 siswa (82,35\%). Hal ini menujukkan terjadinya peningkatan banyaknya siswa yang tuntas dari hasil tes KOBB pada siklus III. Kriteria peningkatan berdasarkan gain ternormalisasi dari KOBB siklus I ke KOBB siklus III termasuk tinggi.

Sementara Rerata gain yang merupakan gambaran peningkatan KOBB berdasarkan Siklus III dan Siklus II selengkapnya dapat dilihat pada Tabel 4.

Peningkatan:

$$
\begin{aligned}
g & =\frac{\text { Nilai Siklus III }- \text { Nilai SiklusII }}{\text { Nilai Ideal-Nilai Siklus II }} \\
& =\frac{76,57-68,82}{100-68,82}=\frac{7,75}{31,18}=0,25
\end{aligned}
$$

Kategori gain ternormalisasi: $\mathrm{g}=0,25<0,3$ : rendah.

Tabel 4 memberikan gambaran bahwa rata-rata nilai KOBB siswa pada siklus III lebih tinggi dibandingkan dengan rata-rata nilai siklus II. Demikian juga banyaknya siswa yang tuntas pada siklus III lebih banyak dibandingkan dengan siklus II. Hal ini menujukkan terjadinya peningkatan banyaknya siswa yang tuntas dari hasil tes
KOBB pada siklus III. Akan tetapi, kriteria peningkatan berdasarkan gain ternormalisasi dari KOBB siklus II ke KOBB siklus III termasuk rendah.

\section{B. Pembahasan}

Langkah-langkah CAI-Contextual dalam penelitian ini diadopsi dari hasil pengembangan CAI-Contextual oleh Nanang (2019) sebagai berikut.

\section{Awal Pembelajaran.}

Diawal pembelajaran peneliti memulai dengan ceramah untuk memotivasi siswa. Selanjutnya Guru dan siswa melakukan pembentukan kelompok untuk menciptakan komunitas belajar. Satu kelompok sekitar 4 atau 5 siswa dan 1 komputer/laptop seperti tampak pada Gambar 1.

Selanjutnya Guru mengajukan beberapa Tabel 4

Ketuntasan dan Peningkatan Siklus III dari Siklus II

\begin{tabular}{lcccc}
\hline & Siklus III & Siklus II & g & Kriteria \\
\hline $\begin{array}{l}\text { Rata- } \\
\text { rata }\end{array}$ & 76,57 & 68.82 & 0,25 & Rendah \\
\begin{tabular}{|lccl} 
Subjek \\
yang \\
Tuntas
\end{tabular} & 28 & 23 & & \\
\hline $\begin{array}{l}\text { Subjek } \\
\text { yang }\end{array}$ & 6 & 11 & & \\
$\begin{array}{l}\text { Tidak } \\
\text { Tuntas }\end{array}$ & & & & \\
Catatan: Nilai ideal KOBB 100 dan KKM 65 &
\end{tabular}

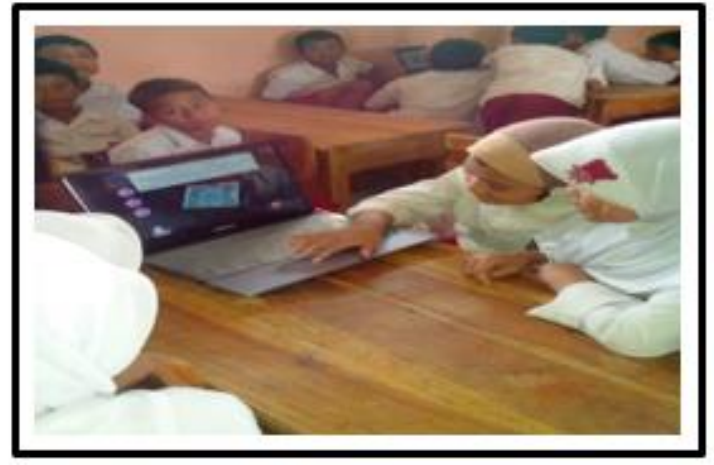

Gambar 1. Siswa belajar secara berkelompok. 
pertanyaan secara lisan kepada siswa untuk menggali pengetahuan awal siswa. Misalnya guru bertanya kepada siswa tentang banyak roda sebuah sepeda motor. Selanjutnya guru bertanya banyaknya seluruh roda kalau sepeda motornya ada 5. Guru bertanya kepada siswa tentang cara menghitung banyak roda dari kelima sepeda motor tersebut. Guru bertanya lagi kepada siswa sampai diketemukan cara menghitung jumlah roda dari kelima motor tesebut dengan menggunakan sifat perkalian.

\section{Diskusi}

Pada saat pembelajaran siswa diberi tugas berupa menyelesaikan soal-soal baik dikelas (lihat gambar 2) maupun dirumah. Tugas tersebut berupa penyajian masalah Contextual menggunakan ilustrasi di komputer. Sebagai contoh "Hitunglah jumlah seluruh roda dari 5 buah sepeda, lalu buatlah

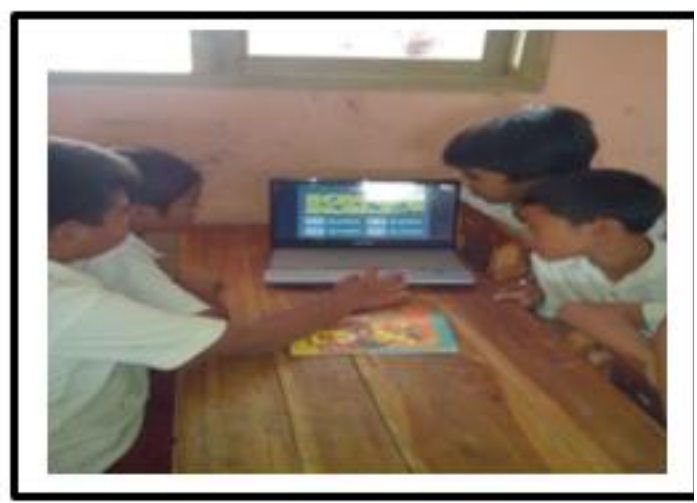

Gambar 2. Menanamkan konsep perkalian.

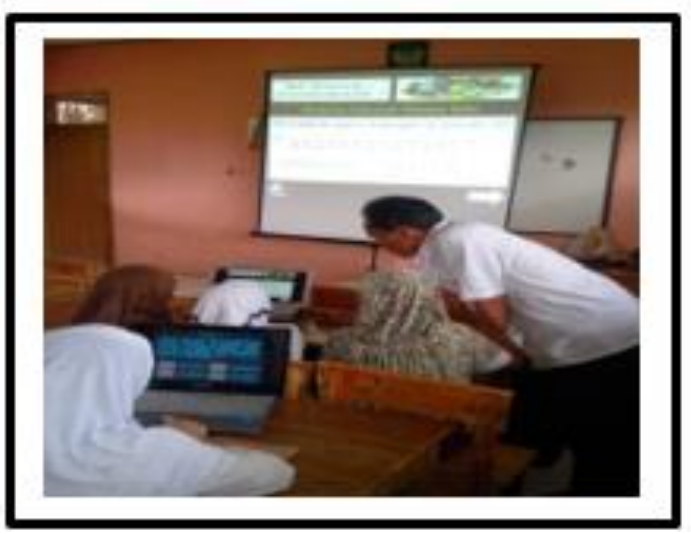

Gambar 3. Siswa secara mandiri menyelesaikan soal Contextual. menjadi konsep perkalian!".

Guru mempersilahkan siswa untuk mempelajari materi pelajaran dan mengerjakan masalah Contextual secara sepintas sebelum dimulai diskusi kelompok. Guru sebagai fasilitator memberikan kesempatan kepada siswa untuk bertanya agar sampai kepada solusi masalah Contextual yang diajukan.

\section{Kemandirian}

Siswa secara mandiri menyelasaikan soalsoal cerita lainnya dalam software pembelajaran (lihat gambar 3).

\section{Tahap Refleksi dan Merangkum.}

Apabila proses pemecahan masalah sudah benar, kemudian guru mengajukan pertanyaan pada siswa (lihat gambar 4), misalnya: bagaimana jika?, apakah ada cara lain? Coba kerjakan dengan cara lain! Siswa menjelaskan bagaimana menggunakan

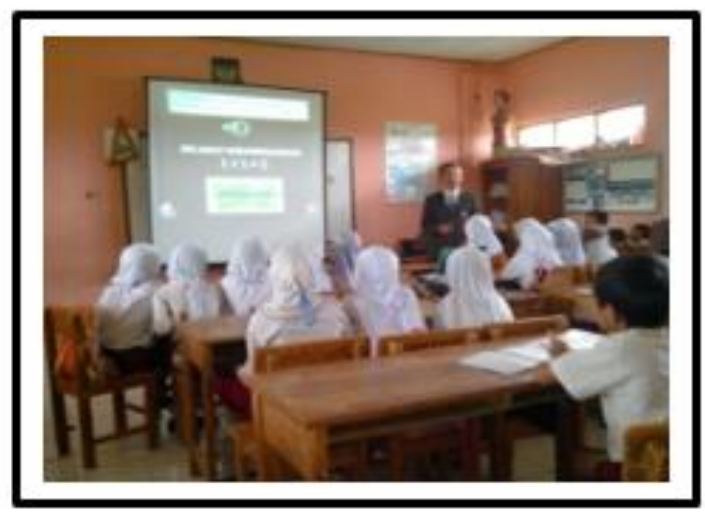

Gambar 4. Kegiatan refleksi dan merangkum.

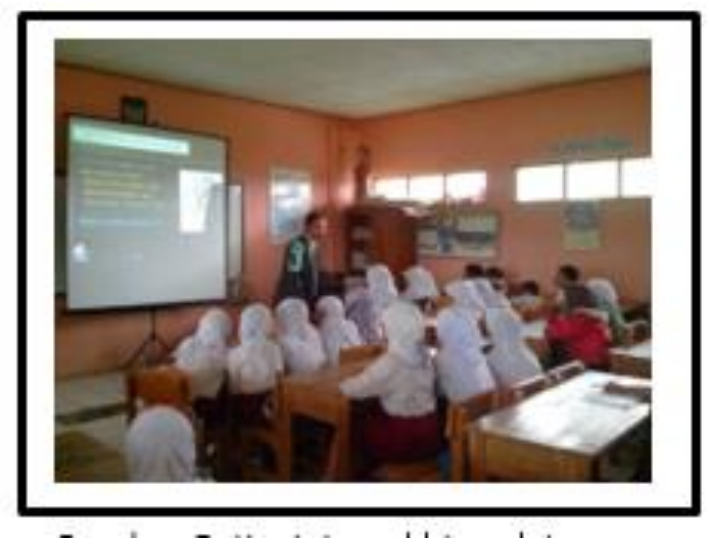

Gambar 5. Kegiatan akhir pelajaran. 
strategi spesifik untuk memecahkan masalah tertentu.

\section{Menutup Pelajaran}

Diakhir pembelajaran sebagai penutup pelajaran, guru tidak hanya mengucapkan salam sebagai perpisahan, akan tetapi dapat dimanfaatkan untuk menumbuh-kembangkan jiwa juang siswa. Caranya adalah siswa diberi tugas menyelesaikan soal-soal non-rutin di rumah secara berkelompok. Adapun pelaksanaannya, guru mengulas kembali tentang konsep yang baru saja dipelajari, kemudian mengarahkan $s$ iswa untuk merangkum materi pelajaran yang dianggap penting (lihat gambar 5). Guru memberikan soal-soal latihan untuk dikerjakan di rumah.

Langkah-langkah CAl-Contextual di atas berpotensi meningkatkan hasil belajar matematika (khususnya meningkatkan kemampuan operasi bilangan bulat. Hal ini senada dengan beberapa temuan (Afriansyah, 2012) tentang kemampuan Operasi Bilangan Bulat (KOBB) dalam CAI-Contextual yang dianalisis berdasarkan siklus. Secara lengkap hasil temuan tersebut dibahas pada bagian berikut.

Hasil penelitian menunjukkan bahwa berdasarkan hasil tes KOBB tiap siklus, KOBB siswa pada siklus II dan III berbeda secara signifikan atau lebih baik dari pada siklus I. Sedangkan KOBB siswa pada siklus II tidak berbeda secara signifikan atau lebih baik dari pada KOBB siswa pada siklus III. Hal ini dikarenakan peningkatan KOBB dari siklus II ke siklus III berkategori rendah. Namun demikian, rata-rata nilai KOBB siswa pada siklus III lebih besar daripada rata-rata nilai KOBB siswa pada siklus II.

Temuan di atas didukung oleh perolehan rerata skor gain ternormalisasi, pada siklus III sebesar 0,72 (peningkatan dari siklus I cukup tinggi), pada siklus $\|$ sebesar 0,62 (peningkatan dari Siklus I termasuk sedang). Selain itu, didukung pula oleh hasil perbandingan ketuntasan belajar. Berdasarkan hasil tes KOBB diperoleh informasi bahwa jumlah siswa yang tuntas meningkat terus dari siklus I, II, dan III.

Hasil temuan ini didukung oleh banyaknya siswa yang tuntas pada tiap siklus. Untuk KKM 65, pada siklus I banyaknya siswa yang tuntas ada 13 siswa (38,24\% dari 34 siswa), pada siklus II banyaknya siswa yang tuntas ada 23 siswa (67,65\% dari 34 siswa), dan pada siklus III banyaknya siswa yang tuntas ada 28 siswa (82,35\% dari 34 siswa). Tampak bahwa pada siklus III, ketuntasan secara klasikal (85\% siswa mencapai ketuntasan) hampir tercapai.

\section{Penutup}

Berdasarkan hasil analisis data serta pembahasan yang telah dilakukan, maka penelitian dapat mengambil kesimpulan yaitu pembelajaran Contextual tanpa CAI dapat meningkatkan KOBB siswa dari pembelajaran tanpa CAl-Contextual dengan kriteria sedang, CAl-Contextual dapat meningkatkan KOBB siswa dari pembelajaran tanpa CAI-Contextual dengan kriteria tinggi, dan CAl-Contextual dapat meningkatkan KOBB siswa dari pembelajaran Contextual dengan kriteria rendah.

Selain hasil penelitian utama yang disimpulkan di atas, penulis juga menyimpulkan hasil penelitian sampingan yang berkaitan dengan siswa Kelas $\mathrm{V}$ SDIT Miftahul Ulum yaitu pengetahuan awal matematik (PAM) siswa sebelum penerapan CAI-Contextual termasuk rendah. Dengan kata lain, penguasaan siswa terhadap materi yang 
sudah diajarkan pada semester 1 termasuk rendah. Kenyataan ini menunjukkan bahwa daya ingat siswa terhadap materi pelajaran yang sudah diajarkan termasuk rendah.

Selain itu, ketercapaian nilai KKM sebesar 65 dalam skala 100 oleh siswa di setiap siklus melalui CAl-Contextual adalah KOBB siswa pada siklus I untuk topik operasi penjumlahan dan pengurangan bilangan bulat melalui penerapan CAI-Contextual dengan cara siswa berkelompok mengerjakan LKS belum mencapai KKM. Sedangkan KOBB siswa pada siklus II untuk topik operasi perkalian bilangan bulat melalui penerapan CAI-Contextual dengan cara siswa berkelompok mengerjakan LKS dan menggunakan kartu soal telah mencapai KKM. Adapun KOBB siswa pada siklus III untuk topik operasi pembagian melalui penerapan CAI-Contextual dengan cara siswa berkelompok mengerjakan LKS dan guru membimbing siswa dalam mengubah soal cerita ke dalam bentuk model matematika telah mencapai KKM.

Berdasarkan hasil penelitian yang telah ditemukan dan pembahasan serta atas dasar kesimpulan, peneliti mengusulkan beberapa saran yaitu CAI-Contextual dapat dijadikan sebagai alternatif guru dalam pembelajaran matematika. Hal ini dikarenakan strategi CAIContextual berpengaruh posiitif terhadap kemampuan pemahaman dan pemecahan masalah matematis siswa. Selain itu, dalam mengimplementasikan strategi CAI-Contextual dengan tujuan meningkatkan kemampuan pemahaman dan Operasi Bilangan Bulat siswa, guru perlu meningkatkan kemampuan penggunaan komputer sebagai media pembalajaran. Seorang guru harus kreatif dan inovatif dalam memanfaatkan media pembelajaran yang tersedia di sekolah ataupun kreatif membuat media pembelajaran sendiri dengan menggunakan lingkungan sekolah. Terakhir, dalam upaya meningkatkan kualitas proses pembelajaran diperlukan dukungan nyata dari satuan pendidikan dalam hal ini kepala sekolah dan jajarannya untuk menyediakan sarana dan prasarana yang diperlukan untuk mecipkatan situasi pembelajaran di kelas sesuai dengan yang diharapkan. Adapun sarana dan prasarana penting yang dituntut untuk dapat melaksanakan strategi CAI-Contextual adalah sebagai berikut: jaringan listrik yang memadai disetiap kelas, perangkat computer (laptop), dan infocus. Dalam Hal ini bukan tidak ada lagi alasan ketiadaan dana, karena pemerintah pusat sudah memberikan bantukan dana pendidikan berupa BOS yang diterima oleh sekolah mulai dari SD.

\section{UCAPAN TERIMA KASIH}

Penelitian ini didanai oleh DRPM Dirjen Ristek Dikti.

\section{DAfTAR PUstaka}

Afriansyah, E. A. (2012). Implementasi PMRI dalam Materi Sifat Komutatif dan Assosiatif pada Bilangan Bulat untuk Level Siswa SD/MI. Mosharafa: Jurnal Pendidikan Matematika, 1(2), 66-72.

Afriansyah, E. A. (2014). Addition and Substraction Numbers up to 10 through PMRI for SD/MI Level Students. International Postgraduate Colloqium of Research in Education 3rd IPCORE 2014 Universitas Pendidikan Indonesia.

Afriansyah, E. A. (2016). Makna Realistic dalam RME dan PMRI. LEMMA, 2(2), 96104.

Afriansyah, E. A., Puspitasari, N., Luritawaty, I. P., Mardiani, D., \& Sundayana, R. (2019). The analysis of mathematics with 
ATLAS.ti. Journal of Physics: Conference Series 1402 (7), 077097.

Arikunto, S (2008). Penelitian Tindakan Kelas. Jakarta: Bumi Aksara.

Damayanti, R., \& Afriansyah, E. A. (2018). Perbandingan Kemampuan Representasi Matematis Siswa antara Contextual Teaching and Learning dan Problem Based Learning. JIPM (Jurnal IImiah Pendidikan Matematika), 7(1), 30-39.

Deni. (2018). RPP Matematika K13 Kelas 6 Semester 12 Revisi 2018. https://dicariguru.com/download-rppmatematika-k13-kelas-6-semester-1revisi-2018/

Fuadiah, N. F. (2017). Hypothetical Learning Trajectory pada Pembelajaran Bilangan Negatif Berdasarkan Teori Situasi Didaktis di Sekolah Menengah. Mosharafa: Jurnal Pendidikan Matematika, 6(1), 13-24. DOI: https://doi.org/10.31980/mosharafa. v6i1.290

Latipah, E. D., \& Afriansyah, E. A. (2018). Analisis Kemampuan Koneksi Matematis Siswa Menggunakan Pendekatan Pembelajaran CTL dan RME. Matematika, 17(1).

Meltzer, D. E. (2002). Addendum to: The Relationship Between Mathematics Preparation and Conceptual Learning Gains in Physics: A Possible "Hidden Variable" in Diagnostics Pretest Scores. Vol. 70. Page 1259-1268. [online]. Tersedia: [9 Oktober 2016]

Nanang. (2016). Pengembangan CAIContextual untuk meningkatkan kemampuan berpikir matematik dan karakter mahasiswa. Jurnal Penelitian Pendidikan dan Pengajaran Matematika (JP3M): 123-134. http://jurnal. unsil.ac.id/

index.php/jp3m/article/view/164.

Nanang. (2018). Kemampuan pemecahan masalah matematik mahasiswa melalui pembelajaran mathematic in context. Jurnal Penelitian Pendidikan dan Pengajaran Matematika (JP3M), 4(1), 2734.

http://jurnal.unsil.ac.id/ index.php/jp3m/article/view/NAN41.

Nanang. (2019). Pembelajaran Matematika SD Berkarakter Berbasis CAI-Contextual Menggunakan Lab Virtual. Jurnal Pena Karakter (Jurnal Pendidikan Anak dan Karakter), 2(01), 43-52. http://ejournal.hikmah university.ac.id/ index.php/jpk/article/view/224.

Sanjaya, W. (2016). Strategi Pembelajaran Berorientasi Standar Proses Pendidikan. Jakarta: Prenadamedia Group.

Setyaningsih, N., Ariyanto, \& Khotimah (2006). Aplikasi Pendekatan Model Kooperatif dalam Pembelajaran Matematika. https://www.researchgate.net/publicatio $\underline{n} / 279690201$

Sipayung, A. (2018). Meningkatkan Pemahaman Konsep Matematika tentang Sifat-Sifat Bangun Ruang Sederhana melalui Contextual Teaching and Learning. Mosharafa: Jurnal Pendidikan Matematika, $\quad$ 7(3), 401-412. DOI: https://doi.org/10.31980/mosharafa. $\underline{\mathrm{v} 7 \mathrm{i} 3.153}$

Siregar, I. (2016). Masalah Pembelajaran Pembuktian Matematika bagi Mahasiswa di Indonesia. Mosharafa: Jurnal Pendidikan Matematika, 5(3), 315-324. DOI: https://doi.org/10.31980/mosharafa. $\underline{\mathrm{v} 5 \mathrm{i} 3.286}$

Somakim. (2010). Peningkatan Kemampuan Berpikir Kritis dan Self-Efficacy Matematik 
Siswa Sekolah Menengah Pertama
dengan Penggunaan Pendekatan

Matematika Realistik. Disertasi. SPs UPI

Bandung: Tidak diterbitkan.

Sopian, Y. A., \& Afriansyah, E. A. (2017).

Kemampuan Proses Pemecahan Masalah

Matematis Siswa Melalui Model

Pembelajaran Creative Problem Solving

dan Resource Based Learning. Jurnal

Elemen, 3(1), 97-107.

Sutrisno, J. (2013). Pemecahan Masalah

Sebagai Tujuan dan Proses Dalam

Pembelajaran Matematika. Lentera Jurnal

Kependidikan.

https://lenterastkippgribl.blogspot.com/2

013/02/pemecahan-masalah-sebagai-

tujuan-dan.html.

Suwarto. (2018). Konsep Operasi Bilangan

Pecahan melalui Garis Bilangan.

Mosharafa: Jurnal Pendidikan

Matematika, $\quad$ 7(3), 327-336.

DOI: https://doi.org/10.31980/mosharafa. v7i3.73

Tarlina, W. H., \& Afriansyah, E. A. (2016). Kemampuan Berpikir Kreatif Siswa

Melalui Creative Problem Solving. Eduma:

Mathematics Education Learning and Teaching 5 (2), 42-51.

Tentorku. (2015). Gangguan Belajar

Matematika. https://www.tentorku.

com/gangguan-belajar-matematika-

diskalkulia/

\section{Riwayat Hidup Penulis}

\section{Dr. Nanang, M.Pd.}

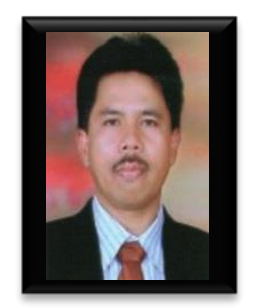

Lahir di Bandung, 1 Juli 1964. Staf pengajar di Jurusan Pendidikan Matematika IPI Garut. S1 Pendidikan Mate-matika IKIP Bandung, lulus tahun 1989; S2 Pendidikan Matematika IKIP Surabaya, lulus tahun 1999; dan S3 Pendidikan Matematika UPI
Bandung, lulus tahun 2009.

Awan Sukandar, S. Pd., M. Pd.

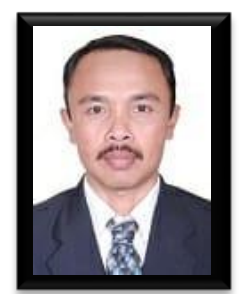

Lahir di Garut, o9 Mei 1967. Staf pengajar SDIT Miftahul Ulum. S1 Prodi Bahasa dan Sastra Indonesia STKIP Garut, lulus tahun 2006; S2 Teknologi Pendidikan STKIP Garut, lulus tahun 2014. 